\title{
THE TRANSNATIONAL SUCCESS OF COSMOPOLITAN MAGAZINE
}

\author{
Ekawati Marhaenny Dukut \\ English Department, Faculty of Letters, Soegijapranata Catholic University Semarang. \\ ekawatimd@gmail.com
}

\begin{abstract}
Studying about an American popular culture product such as the Cosmopolitan magazine for American Studies' scholars can no longer be framed in studying how it is operated within the U.S. only. Instead, a look at how it is being transferred across nation's borders and how it is regulated in other nations become a concern also to scholars. Time and space is no longer a border for a world that is transnational, so global values that are being sold in the magazine's advertisements are being made continually popular by inserting local ideas. How has Cosmopolitan successfully achieved its globality? The following article discusses on the transnational culture that Cosmopolitan and its magazine advertisement brings and how it has taken in the local to support the global.
\end{abstract}

Key words: Cosmopolitan, Global, Local, Transnational, Popular culture

\section{INTRODUCTION}

Ever since 2004, American Studies scholars are encouraged to use transnationalism in their methodology. This means that scholars are asked to look "beyond the nation's borders" when criticizing a piece of work, because the U.S. culture originated from a migration of cultures (Fishkin, 2004, p.21). With the coming of different cultures into the U.S., transnationalism paved the way for whatever is popular in the U.S. to be as equally popular in other nations. This can be possible whenever the U.S. people originating from these multi-cultures have a chance to return to their origins and spread the idea of for example, the benefit of the already popular culture of the U.S. supermarkets, fastfood chains and credit cards.

The word transnational is sometimes inter changeable with the words "international, multinational, global", and "supranational" (De Mooij, 2004, p.6), that connotes "boundarylessness" so that a Coca-Cola can be travelling around the globe and being drank by a "Black, White, Middle Eastern, East and South Asian, who is beating his own indigenous drums to the beat of the Coca Cola jingle" (Rao, 1996, p.1). According to Haque (Haque, 2011, p.1) transnationalism is globalization, and is usually associated with the free market-based classical liberal economic policies pursued by developing and transnational societies of the world, that have embraced Western, more precisely, American values and modes of doing things not only in the realm of economics and politics but more visibly in the production, consumption and circulation of popular culture products, manifested in a pervasive process of commodification of advertising.

With regards to advertising, in addition to those posted on the internet where its usage is continually climbing at astounding rates on a worldwide basis (Roberts \& Hajun, 2001, p.18), the traditional pages of print advertising in magazines are still popularly used as publication and promotion media. Feng and Frith (Feng \& Frith, 2008, p.2) informs that ever since the 1900s, advertisements from the back of especially women magazine pages were moved to the front because they were a good source of revenue. Years later, the advertisements are also integrated with editorials. With advertorials 
special position, therefore, many transnational advertisers use the chance to globalize women magazines. The expansion of women magazines crossing the borders have been made possible with global media corporations' franchise systems that produces international women's magazines. Thus, making advertisements in international women's magazines have a globalized culture.

The globalized culture that advertisements have is in making their readers, who are potential consumers to not onlywatch, but also dream, and eventuallybuy things. Having the advertisements go transnational, therefore, makes corporations or organizations think of how to sell the American dream for Europeans or Asians. How it is possible to sell an American Barbie to a Japanese or an Indonesian, is a clause of example. One best way to do is to create valuable images and make consumers addicted to it (Transnational Advertising Culture). This is why, nowadays, “joy and happiness are perfumes" and "love-and-caring and hope are cosmetics" for most women of the world (Kavanaugh, 2013). One of the most popular women's magazines which enjoy global success is the Cosmopolitan. Below is a recount of its history and how Cosmopolitan later achieved its transnational success story.

\section{THE SUCCESS STORY OF COSMOPOLITAN MAGAZINE}

Cosmopolitan magazine started its business in the U.S. in 1886 and since that time, it the magazine experienced a management of various owners (Simkin, 2013). First, it was owned by the founders, Schlichtand Field, who initially intended the magazine to be read for the family because there were articles devoted exclusively for the caring and management of children, cooking, household decoration, and other interests for women such as fashion. In addition to this, articles for the younger members of the family were available.
Eventhough this domesticated magazine managed to reach a circulation of 25,000 in its first year, the founders could only manage the business for two years (Simkin, 2013). By 1889 the magazine was owned by John Brisben Walker, who appointed E.D. Walker as his editor. The new editor made the magazine more attractive, by providing colorful illustrations, serials and book reviews. Serial stories from Theodore Dreisser, Rudyard Kipling, Jack London, Willa Cather and Edith Wharton were among those that help built up Cosmopolitan as a popular literary magazine. Thus, by 1892 its circulation climbed up to 75,000 and made Cosmopolitan one of America's leading literary magazine. Walker's management, however, was successful for only around ten years. William Randolph Hearst became the next owner to have bought the Cosmopolitan for US \$400 in 1905. In his ownership, well-known journalists and top illustrators were hired to help him publish a literary magazine which had three serials and ten short stories. Due to its popularity, its circulation rise up to $1,700,000$ with an advertising income of $\$ 5,000,000$ in 1930. A decade after, the circulation amount was then increased up to 2,000,000 during World War II. Yet, due to the rise of paperbacks and television, there was a decrease in the demand for fiction in the 1950s' Cosmopolitan. This decrease continued on for a decade, until Helen Gurley Brown took over as chief editor in 1965.

In Brown's hands, she refocused the literary magazine into a magazine for women. The change from a literary to a women's magazine was because the 1960's was also the rise of feminism. In this decade, women demonstrated against their daily domesticated role as housewives and other forms of discrimination such as the lower pay and fewer promotions for women at the work force. It was in this decade that women are taught to believe that they, too, have the abilities to have political and academic achievements (Friedan, 1963, p.348). 
With the above condition, therefore, Brown cleverly made the Cosmopolitan magazine as a media that can give support and advice to women on how to deal with their new roles. Her message of 'Live big, go for it, be the best you can be in every area of your life' and vision for women to be 'fun, fearless female' was popular among women readers. She envisioned that a woman may still want to be traditional in many ways, but did not want to get her identity from other people because she wanted to achieve on her own. Therefore, she made the magazine to "serve career women in their 20 s and 30 s by writing openly on topics such as sex and personal relationships including premarital and extramarital affairs" (Sternadori 2). Other women's magazine had also treated sex as a subject but they were most often in the context of its domestication (Ehrenreich and English). In Cosmopolitan, sex was discussed as a "function of the public sphere, in the context of the workplace, and in the explicit terms of the marketplace" (McMohan, 1990, p.382). By 2001, the Cosmopolitan reached a much greater popularity among young women with a circulation of 2,963,351 in the U.S. (Pan, 1993, p.8).

Cosmopolitan is continually popular. It is more than a magazine, it is an "empire, a brand, a state of mind" (Taylor, 2003, p.7). With a target audience of young, ambitious, and informed women, most readers are employees, who have earnings and time to spend. It is for this reason that advertisers would look into Cosmopolitan to advertise their products. For example, Taylor (Taylor, 2003, p.7-8) reports that in the United Kingdom (U.K.), Cosmo women would spend over one billion a year on fashion, two billion on their homes, 3.5 billion on food, 1.4 billion on new cars and account for 1 out of 11 spent on cosmetics and skincare. It is also in Cosmopolitan that readers rely on as a girlpower guide to getting things right. Citing Kesley, Cosmopolitan magazine is regarded
More insightful and intimate than the best friends, more of an instant feelgood fix than the bubbliest of champagnes, more saucy and sinful than the most calorific of chocolates, Cosmo is the relationship bible for today's modern young woman. It's fun, fearless and fabulously flirtatious attitude is a manifesto for her life (Taylor, 2003, p.8).

Cosmopolitan is basically a magazine that women would use as a guide. It has established a brand, too. In 2001 the National Magazine Company launched Cosmo GIRL! and Cosmopolitan Bride. There is also a Cosmo TV with 3 TV networks, 2 Spanish language channels, one in Spain and one in Latin America, and an English channel in Canada launched in February 14th, 2008. Cosmo Radio airs in Sirius Radio XM162 in the U.K. and also targets its listeners of the 18 to 34 age group (Kesley, 2003).

Cosmopolitan's success story is also partly owed to the condition that women are the largest consumers. It is the women rather than men that "spend more time on shopping, banking, and sending e-greeting cards" (Pan, 1993, p.5). Women are seen to be financially powerful with an "expenditure of about $\$ 2$ trillion per year in the U.S. because in the family, they are usually in charge of the families' daily finances" (Pan, 1993, p.6). Because it is predicted that $\$ 12.5$ trillion will be passing through women's hands in between the years of 2010 and 2015, thus, ever since 2004, the Cosmopolitan was expanded internationally with 25 languages and reaches the women of Argentina, Australia, Brazil, Chile, China, and other nations (Pan, 1993 p.8).

In 2010, the prediction is proven true. The latest data in 2013 showed that the Cosmopolitan magazine was recognized as the most popular magazine in the world because it had 64 
international editions, printed in 35 languages international editions, printed in 35 languages and distributed in more than 100 countries (Cosmopolitan magazine). The numbers mentioned here are mostly related to the print magazines. Nowadays, with digital magazines on the internet, its popularity is more than ever on the rise. Ever since it made itself available on the Zinio platform in 2005 and much later on the Ipad, the magazine definitely gained exceptional popularity with its 100,000 individual subscribers.

Helen Gurley Brown And her's Cosmopolitan Message

The name Cosmopolitan is not only a magazine label, but literarily to show that it is intended for the modern, outgoing cosmo or modern women of the 18-34year old range. For the 32 years as editor, this Cosmo-ness to Brown has been translated into the revolutionary idea that "women working outside of the home can have sex, including sex outside of marriage" (McMohan, 1990, p.382). Because the magazine explicitly puts on many things about sex, it becomes the reason for people to have the attribute that Cosmopolitan magazine means sex. As explained above, it was Brown that promoted the running theme of placing importance to women's sexual desire as a working goal for the magazine. It was not the first time she did this. Back in 1962, she was successful in her then-scandalous self-help book Sex and the Single Girl, which sold 2 million copies in three weeks in 35 countries and made the bestseller lists in the Los Angeles Times, The New York Times and Time (Scanlon, 2009, p.1).

In her book, Sex and the Single Girl, Brown (Brown, 1962, p.1) encouraged single women to advance their situation of being alone by being daring and finding suitable partners. Through a list of men available in a woman's life, Brown suggested in one of her book's chapters for where women should meet men and how to keep a good healthy shape, so women can maintain their sexy outlook. Other chapters of Brown's book showed how women could become a good home maker and manager by becoming a good home decorator, cook, and child manager, yet also having financial independence and have freedom to sexual relationships regardless of whether a woman is still single or already married. Although receiving many critics at a time when Cosmopolitan was already famed as the foundering for monthly fiction, it was these initial ideas for women who should have a "sexual desire" and "financial self-sufficiency" (Simmons-Duffin, 2012) that Brown persistently transfers to the Cosmopolitan magazine. This is why, with Kate White as the current editor, she could instruct almost every issue of Cosmopolitan to have the word sex explicitly written on the covers and articles' headlines.

With regards to the running theme of sexual desire, based on a research that McMohan (McMohan, 1990, p.384) did to a selection of articles from the 38 issues of the 1976 to 1988 Cosmopolitan magazines, she found 77 articles talking about relationships with men, 51 articles on the lives of celebrities and 49 articles explicitly offering advice about sex. Yet in the 49 articles she mentioned are misleading because in reality their articles about relationships with men, and the lives of celebrities contained sexually explicit material and deal with sexual relationships and problems (McMohan, 1990, p.385). Consequently, it is logical to see many vocabularies and phrases, which connote the theme of sexuality throughout many of the magazine's issues. In the U.S. August 2012 issue, for example, the following phrases are found: "52 Sex Tips", "When Your Vagina Acts Weird after Sex", "50 Kinky Sex Movies" and "His Best Sex Ever" (Zimmerman, 2012). Interestingly enough, it is this particular message that is being maintained globally by many other countries. As informed by Pan above, Cosmopolitan has been distributed in 
Argentina, Australia, Brazil, Chile, China, and other nations. Zimmerman also says that the other nations or countries also include Armenia, Azerbaijan, Britain, China, Croatia, Finland, France, India, Indonesia, Middle East, Mongolia, Russia, Singapore, South Africa, South Korea, and Vietnam

When Cosmopolitan is globalized, it means that the U.S. magazine's version gets to be read by people of different countries. It may also mean that some articles or advertisements from the original U.S. version are directly translated from the English language to the different nation or countries' languages. Yet most of the time it is the magazine's messages that are transnationalized by bringing the global into the local. This means that the article on for example, "His Best Sex Tips" may be a show and tell of the local people's experiences rather than just taking for granted the ones directly from the U.S. with no changes whatsoever.

As a transnational magazine, Cosmopolitan relies on a global strategy, dealing with a private 50-page manual, which dictates criteria in the selection of cover models and editorial focus (Nelson \& Paek, 2005, p.372). For example, the woman on the cover is "always a woman, with large hair, remarkable features and not too much clothing" (Carr). This becomes understandable for why a Russian Cosmopolitan co-editor then comments, "Hearst is a great partner, as long as you don't put a guy on the cover" (Carr).

\section{APPLICATION OF COSMOPOLITAN'S TRANSNATIONALITY}

Samples on how Cosmopolitan applies transnationality throughout the globe are illustrated as follows. In Indonesia, the Cosmopolitan changed the way Indonesian women think about sex. It used to be a taboo topic, but now it can be discussed openly. Originally called Cosmopolitan Higina, the initial September 1997 made its breaking new ground of promoting sexually assertive women (Saraswati, 2010, p.21). Upon this fact, Saraswati (Saraswati, 2010, p.22) commented that although there were protests from some Muslim groups in Indonesia that women became to love sex too much, it was nonetheless this sexuality issue that made Cosmopolitan a great hit and has a circulation of 139,000 in the year of 2004. To state yet another transnational example is in Russia's Cosmopolitan edition. Because young Russians cannot afford to move out from their parents' homes, the editor then released an article on how to have sex while living with their parents (Carr).

With regards to other countries, it is written that in India the message received by the readers is that Indian women can marry someone whom they like and not because their parents told them to (Zimmerman, 2012). Because Indian women traditionally live with their parents until marriage, the teachings that women can go out and find their own men is a culture that needs to be accustomed. In Singapore, whenever a sexual content is published a yellow warning box with the writings: 'Unsuitable for the Young' would run on the cover. For the Middle East, dating and premarital sex are punishable by law, so the editor had to treat the issue of sex carefully. In South Korea, articles on sex are not as popular as the 'dreamy wedding' ones, so pages of the magazine are inclined to have lots of fashion wear and accessories for the bride-to-be. In Finland, to change the notion that Finnish guys are not hot, most of the centerfold type pages are filled with topless Finnish guys. For nations, who are not overly interested with sex issues, the editors of Cosmopolitan have made ways for ideas that would sell better. For example, in Kazakhstan, readers are more interested in articles on career and travel rather than sex, because as a newly independent and developing nation, their women are more interested in the kinds of career opportunities and economy the 
market has to offer. In Croatia the topics on how women could act bravely on their own have been the most popular. For Germany, it is business-oriented issues that become a hit.

In obtaining its materials, Chang (Chang, 2001, p.3) explains that Cosmopolitan has both "centralized and localized" qualities. Various editions from many countries can borrow materials from a "central bank", which is from the New York headquarters. The borrowing can also be from the "sister bank" of other countries, thereby, making Cosmopolitan unique as it blends the global and local topics concerning womanhood. This model allows a "parent company to build up branches or subsidiary networks of local agents and in this way, they can establish important connection and alliances in foreign markets" (Feng \& Frith, 2008, p.2). What usually happens when new magazine editions are to be published, local publishing companies form joint ventures with the head office of the international publishing company. Then the staff from the head office will be sent to train the staff and editors in the new foreign office to receive text and pictures from the head offices. By making use of the parent publication's brand name, reputation, format, and experience the local editions of the international magazines have more of a chance to attract international advertisers.

Technically, a team of staff members at Cosmopolitan headquarters would usually create the initial ideas for the articles and have them transferred to the Cosmopolitan network around the globe (Zimmerman, 2013). The magazine has a database for international editors to see what features the U.S. headquarters have in mind three months beforehand. Once the images and layout for the featured articles are uploaded, each international editor can adjust the contents according to their own countries' needs. The following is an illustration: what appeared as 'Fascinating Breast Fact' in the U.S. July 2011 Cosmopolitan which featured a close-up of a woman tugging her shirt open, became ' 15 Facts You Need to Know About Your Breasts' in the October 2011 edition of Cosmo Middle East, where it ran a model demurely dangling a bra over her shoulder. 'What His Sleep Habits Can Tell You' ran in Cosmo U.S. in March 2012 and, months later, appeared in China (same photography but with text translated into Chinese) and in Armenia (different photography). And what ran as the fashion spread 'Motorcycle Diaries' in August 2009 in Cosmo U.S. - featuring an abandoned gas station, denim, plaids, a hot guy and the open road - ran two years later in Cosmo Mongolia with the same blend of denim, plaid, gas station and open road, except the whole thing had been reshot with guys who looked Mongolian (Zimmerman, 2012).

A similar sample on how Indonesian Cosmopolitan has made a transnationalism of the U.S. version is as follows. For example, in her research Dukut found that Hollywood, blonde haired celebrity Brittany Murphy is on the Cosmopolitan cover for the U.S. June 2003, U.S. September 2004, U.S. July 2006, Serbian July 2006 and Indonesia's August 2006 version. All have her as the model, but photographed in different attires. The U.S. June 2003 have her in white, you-can-see blouse with the top part of the unzippered, thus showing the cleavage of her breasts. The length of the blouse is midi length, which deliberately shows off her belly button with the way she wears her tight blue denim. With a blonde hair and no smile on her face, Murphy looks professionally sexy. This sexyness is maintained in the other two U.S. versions, i.e. the September 2004, which has Murphy again showing the cleavage of her 
breasts but now wearing a red, white, black abstract motif party dress. Meanwhile, the July 2006chose Murphy to wear a floral pink dress. In sequence with the U.S. July 2006 is the Indonesian August 2006 version, which shows her in a sexy, tight, red dress, which is just like the Serbian's choice for their September 2006.

Who is Murphy, that she is used in three of U.S. issues and also used for the cover of other nation's issues? She is one of the luckiest celebrities to be on three issues of the prestigious magazine. Kate White tells HollywoodLife.com (Cosmo Editor Fondly Remembers Brittany Murphy) and is known for her upbeat and cheerful demeanor. She is remembered well by fans because in addition to starring a number of Hollywood movies such as Something Wicked (2012), The Ramen Girl (2008), Sin City (2005) and many more. She gained her popularity from the film Girl Interrupted (1999) and Clueless (1995). In addition to cinema movies, she was a leading female performer for a TV film in David and Lisa (1998) and vocal singer for a TV series King of the Hill (1997).that her death at 32 years old had surprised many of her fans.

Inspecting the covers again, an example for the same monthly issue is the May 2009. In it is found that the model in the U.S. version is Whitney Port who had on an orange low cut summer dress with a long blonde hair. By comparison the Indonesian May 2009 edition prefers to have Britney Spears, who is also with long blonde hair, but in white three-piece suit. Although Spears has a formal suit on, the way she stares at the readers and how she clutches her suit and opens her legs while standing with no smile on her face are equally sexy signs for some readers. From these covers, it is learnt from that the transnationality is the myth of beautiful goddess like women, who ought to have a long blonde hair, where through her gaze, readers can feel how confident a woman can be with herself. Referring back to Brown's 'fun, fearless female' concept then it fits with the ideal picture of a financially independent woman who knows what to do with her gifted capabilities.

Inside the magazine, the transnationality of some articles or sections may be exemplified by the May 2009 version. In the U.S. version's onepage section of Hot Sheet: 6 Things Being Buzzed About Right Now it becomes the Indonesian's two-page section of Hot Sheet: 7 Hal yang Sedang Hangat Dibicarakan. In the U.S. version there are small notes on 1. The truth about sloppy kisses, 2.The practice off peacocking, 3. What's not so hot of Pamela Anderson's behavior, 4.Sexed-up sandals, 5. Twitter.com blows up, and an announcement that "a whooping 88 percent of men admit to fantasizing about one of their female coworkers" (White 35). By comparison the Indonesian version has 1. Hang out di Rooftop, 2. Bergembiralah, 3. Halus tanpa cela, 4. Perihal keterlambatan, 5. Waspada Alzheimer, 6. Fisik atau Fakta with one out off four photos showing Ellen DeGeneres and Colin Farrell kissing sloppy, and a small announcement on Tahukah Anda? "69\% pria mengatakan kalau mereka tak akan pernah berselingkuh dari pasangan atau kekasihnya, tapi $32 \%$ pria juga mengaku berfantasi soal kekasih sahabatnya. Wow!". What is the same in both versions is the show of a couple kissing sloppily and the percentages found of men fantasizing about women (Basuki, 2009, p.54-55). The mentioned sample means to show that the editor of the Indonesian magazine do have the freedom of which ideas are to keep, discard, or expand from the U.S. version, so that they go with the local readers' needs, and they do not go over the basic mission of encouraging financially dependent women who know how to deal with their own sexual desires. 
It becomes clear from the discussions above, therefore, that the global message of Cosmopolitan can be made local in order to achieve continual recognition and the increase of revenues. This quality is something that advertisers are on the go for. Thus, even though some themes on sex are repeatable in editions of Cosmopolitan over the world, the magazine is assured in its success of never lackinga world wide readership.

\section{REFERENCES}

Brown, H. G. (1962). Sex and the Single Girl. USA: Bernard Geis Associates.

Carr, David. (May 26th 2002) Romance, in Cosmo's World, is translated in many ways. Retrieved at 18 August 2013 $<$ http://www.nytimes.com/2002/05/26/busin ess/romance-in-cosmo-s-world-is-tran slated-in-many-ways.html?pagewanted $=$ all\&src $=\mathrm{pm}>$.

Chang, Yu-li. (2001). From Globalization to Locali zation: The World's Leading Television News Broadcasters in Asia. Asia Journal of Communicaton 11.1, 1-24.

"Cosmopolitan." Ed. Fira Basuki. May 2009.

"Cosmopolitan." Ed. Kate White. Hearst Communications, Inc, May 2009.

Cosmo Editor Fondly Remembers Brittany Murphy. (2013). Retrieved at 18 August $2013<$ http://okmaagazine.com/get-scoop /cosmo-editor-fondly-remembers-btrittan ymurphy>.

Cosmopolitan (magazine). (11 August 2013). 12 August $2013 \quad<$ http://en.wikipedia.org /wiki/Cosmopolitan_(magazine) $>$.

De Mooij, M. (1994). Advertising Worldwide: Concepts, Theories and Practice of International, Multinational and Global Advertising. 2nd. Great Britain: Prentice Hall International, Ltd.
Dukut, E. M. (2013). Globalization in American Cosmopolitan Advertisements. Research report. Semarang: Soegijapranata Catho lic University, 2013.

Ehrenreich, B. \& D. English. (1979). For Her Own Good: 150 Years of the Experts' Advice to Women. Garden City, NY: Anchor Press/ Doubleday.

Feng, Y. \& Frith K. (2004). The Growth of International Women's Magazines in China and the Role of Transnational Advertising. Journal of Magazine and New Media Research 10.1 (Fall),1-14.

Fishkin, S. F. (2004). Crossroads of Cultures: The Transnational Turn in American Studies Association. American Quraterly 57.1, 1757.

Friedan, Betty. (1963). The Feminine Mystique. New York: Norton.

Haque, S.M. Mazharul. (2011). Introduction: Global Advertising and Values. In Emmanuel, C. A. (Ed.), Advertising in Developing and Emerging Countries: the Economic, Political and Social Context (p.117). USA: Gower.

Kavanaugh SJ. J. (2013). Idols of the Marketplace. Retrieved at 14 August 2013 $<\mathrm{http}$ ://www.medialit.org/readingroom/idols-market place $>$.

Kawashima, T. (2002). Seeing Faces, Making Races: Challenging Visual Tropes of Racial Difference. Meridians: Feminism, Race, Transnationalism 3.1, 161-190.

Kesley, L. (2003). Was it Good for You, too? 30 Years of Cosmopolitan. USA: Robson Books.

McMohan, K. (1990). The Cosmopolitan Ideology and the Management of Desire. The Journal of Sex Research 27.3, p.381396. 
Nelson, M. \& Hye-Jun P. (2005). Cross-Cultural Differences in Sexual Advertising Content in a Transnational Women's Magazine. Sex Roles 53.5/6, p.371-383.

Pan, Ning. (2004). When east Meets West in Cosmopolitan: Covers, Culture and the Influence of Hearst, 1993-2003. College of Communication, Ohio University, 1-91.

Rao, Sangeeta. (1996). "Other"wise: The Selling of Global Cultural Difference. Sanskriti 7.1.

Roberts, M. S. \& Hajun, K. (2001). Global Interactive Advertising: Defining What We Mean and Using What We Have Learned. Journal of Interactive Advertising 1.2, 1827.

Saraswati, L. A. (2010). Cosmopolitan Whiteness: The Effects and Affects of SkinWhitening Advertisements in a Transnational Women's Magazine in Indonesia. Meridians: Feminism, Race, Transnationalism 10.2, 15-41.

Scanlon, Jennifer. (2009). Sensationalist Literature or Expert Advice? Feminist Media Studies 9.1, 1-15.

Simkin, John. (2013). Cosmopolitan Magazine. Retrieved at 4 August $2013<\mathrm{http} / /$ www.
spartacus.schoolnet.co.uk/USAcosmopolitan .htm\#source>.

Simmons-Duffin, Selena. (2012) 'Cosmo' Editor Helen Gurley Brown Dies at 90. Retrieved at $14 \quad$ August $2013 \quad<\mathrm{http}: / /$ www.npr.org/2012/08/13/158712834/cosmo -editor-helen-gurley-brown-dies-at-90>.

Sternadori, Miglena. (2011). Cosmopolitan's Improbable History. Journal of Magazine \& New Media Research 12. 2, Summer, 1-2.

Taylor, Sophie. (2003). How Does Cosmopolitan Magazine Maintain Relevance in an EverFragile Marketplace? Retrieved at 15 August 2013 $<$ sophiesjtaylor.files.wo rdpress.com/2010/01/case-studyreport .pdf $>$. (2010). Transnational Advertising Culture. Retrieved at 17 August $2013<\mathrm{http}$ // timutes.wordpress.com/2010/01/13/transnati onal-advertising-culture>.

Zimmerman, Edith. (2012). How Cosmo Conquer ed the World. Retrieved at 15 August 2013 $<$ http://www.nytimes.com/2012/08 05/magazine/how-cosmo-conquered-theworld.html?pagewanted $=$ all\&_r $=0>$ 